René Robert

Ghislaine Grollier

Jean-Pierre Frat

Cendrine Godet

Michèle Adoun

Jean-Louis Fauchère

Pierre Doré

\section{Colonization of lower respiratory tract with anaerobic bacteria in mechanically ventilated patients}

Published online: 8 October 2003

(C) Springer-Verlag 2003

The online version of the original article can be found at http://dx.doi.org/10.1007/s00134-003-1729-8
R. Robert $(\bowtie) \cdot$ J.-P. Frat · C. Godet · M. Adoun · P. Doré Service de Réanimation Médicale,

Hôpital Jean Bernard CHU,

86021 Poitiers cedex, France

e-mail: r.robert@chu-poitiers.fr

Tel.: +33-5-49444367

Fax: +33-5-49443862

G. Grollier · J.-L. Fauchère

Laboratoire de Microbiologie A,

Hôpital Jean Bernard CHU,

86021 Poitiers cedex, France

\section{Intensive Care Med (2003) 29:1062-1068}

Due to an unfortunate Error Figure 1 was published incorrectly. The correct Figure is shown below.

There is another mistake in the Result section of this article, second paragraph, first and second sentence. The exact number of patients colonized with aerobic bacteria is 21 (and not 22, corresponding to the total number of colonized patients). The sentences should read:

Colonization occurred early in 16 of 21 patients (71.5\%) from whom aerobic bacteria were isolated, four of these patients being colonized on admission. Colonization by aerobic bacteria occurred late in 6 of 21 patients $(28.5 \%)$.

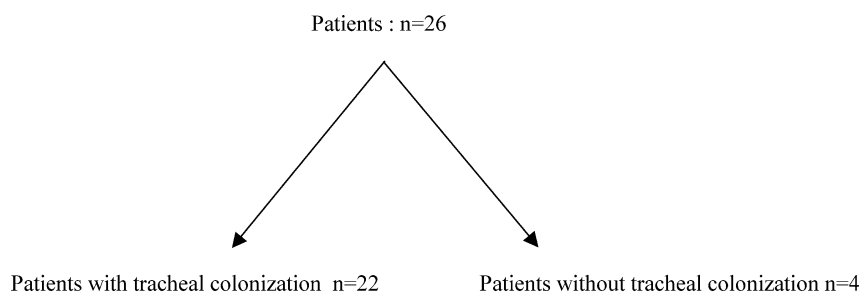

Patients with tracheal colonization $\mathrm{n}=22$

Patients without tracheal colonization $\mathrm{n}=4$

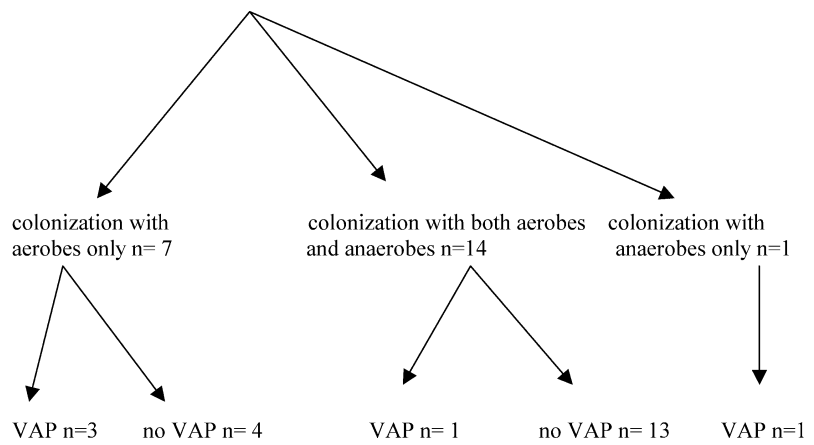

Fig. 1 Distribution of the patients with and without tracheal colonization with aerobic and anaerobic bacteria and with and without ventilatory-acquired pneumonia $(V A P)$ 